\title{
Technological Preferences, Levels of Utilization and Attitude of Students Towards Mobile Learning Technologies in Chartered Universities, Kenya
}

\author{
David Gitumu Mugo ${ }^{1 *}$, Kageni $\mathrm{Njagi}^{2}$, Bernard Chemwei ${ }^{2}$ \\ ${ }^{1}$ Karatina University, P.O. Box 1957-10101, Karatina, Kenya \\ ${ }^{2}$ Kabarak University, P.O. Private Bag-20157 Kabarak, Kenya
}

Corresponding author: David Gitumu Mugo, E-mail: dmugo@karu.ac.ke

\begin{tabular}{l} 
ARTICLE INFO \\
\hline Received: September 26, 2017 \\
Accepted: October 27, 2017 \\
Published: October 31, 2017 \\
Volume: $5 \quad$ Issue: 4 \\
\hline
\end{tabular}

Conflicts of interest: None

Funding: None

\begin{abstract}
The affordances of mobile technologies are being felt in many sectors of world's economy including university education. By solving the limitations of fixed instructional technologies, mobile technologies have received ready acceptance in the education place. The purpose of the study was to investigate the student technological preferences, their levels of utilization as well as attitudes toward mobile technologies. The target population was 30,752 third year undergraduate students in Kenyan Universities. The participants $(\mathrm{n}=375)$ were selected by systematic random sampling. They provided data using self-fill questionnaires. Results indicated that the smartphone was the most popular mobile device; Tecno was the most preferred handset brand; and Android was the most popular operating system. Safaricom was the dominant service provider amongst the student population. Regarding the levels of utilization of mobile technologies by students, it was concluded that though students use their mobile devices sufficiently, the use of the devices for accessing teaching and learning content was considerably low. On the attitude of students towards mobile technologies, it was observed that a sizeable number of students preferred to use the technologies over other existing instructional technologies. The findings of this study will be useful to instructional technologists, education policy makers, mobile handset manufacturers, mobile service providers and university managers as they partner to roll out digital learning infrastructure for Kenyan tertiary education.
\end{abstract}

Key words: Mobile, Technologies, Universities, Utilization.

\section{BACKGROUND}

In recent years, individuals and institutions have adopted Information Communication Technologies (ICT) in their operations. Finance, transport, communication, engineering, education, health and agricultural sectors have openly accepted that ICT can leverage the tasks they do. The technologies are empowering people and institutions, allowing them to radically transform their processes and practices, enabling them to perform their functions in a much improved way (Kandiri, 2014).

A notable trend in the world of ICT is that consumers are orienting their preferences from fixed technologies towards technologies that are mobile. This trend is motivated by the affordances for convenience on one hand and flexibility on the other. Arising from a need assessment, individuals and service providers are working closely with manufacturers so that they design hardware and applications that address the mobile nature of individuals. This strategy has resulted in an even wider acceptance and adoption of the mobile technologies across the various sectors of human endeavors, including education (Mberia, Ofafa, Muathe \& Muli, 2013).

In teaching and learning, the convenience and flexibility offered by mobile technologies is freeing teachers and learn- ers from tethered instructional technologies, transforming mobile devices from simple communication tools to significant tools for learning and information sharing. This scenario is occurring at a time when university students are getting increasingly equipped with high end mobile phones, tablets and laptops, which allow cheap communication as well as convenient ways of sourcing of learning content (Armatas, Holt \& Rice 2005). On the other hand, university lecturers have already realized that mobile technologies can be a good opportunity for them to support learning in novel ways.

In Kenya, the government has underscored that universal access to ICTs is a major driver for national development. The government therefore has supported the development of ICT infrastructure, much of the support being skewed towards the mobile sector which has shown robust growth in the last few years. Growth in the mobile sector has resulted in expansion and widespread usage of the devices, even amongst isolated and disadvantaged demographics. The major network providers are working extremely hard to offer wide range solutions, setting the stage for development of innovation of many other mobile applications, some of which have an educational dimension. Against this backdrop, the 
government of Kenya has been very keen on the provision of technologies that can transform pedagogy and modernize university learning. Through the Commission for University Education (CUE), the government has re-emphasized the critical role that emerging technologies can play in learning with mobile technologies. This study investigated the factors that can encourage the uptake, adoption and utilization mobile technology amongst university students in Kenya.

\section{Objective}

To investigate how technological and student related factors impact on the uptake and utilization of mobile technologies for learning

\section{Research Questions}

1. What are the characteristics of devices owned by Kenyan university students?

2. What are the levels of utilization of mobile devices by Kenyan university students?

3. What is the attitude of Kenyan university students towards learning with mobile technologies?

\section{REVIEW OF LITERATURE}

\section{Mobile Technology and Mobile Learning}

Mobile technology is any portable technology running on an operating system designed for mobile computing. For the purpose of this study, a mobile device is a small, hand-held computing device, typically having a display screen with touch input and/or a miniature keyboard, can incorporate collaborative pedagogy and tailor made resources that can leverage a learning scenario (Clare, 2012). Examples of such devices include laptops, net books, tablets, palmtops, feature phones, smart phones, as well as global positioning system (GPS) devices. These devices have been adopted for mobile learning because they run on modern and powerful telecommunication networks which can support data and internet access (Hosman \& Fife, 2012).

On the other hand mobile learning (also referred as n-learning) is a relatively new field of learning that uses technologies that are mobile, and uses learning spaces that overcome the limitation of time and space (Baharom, 2013). According to Judy (2009), m-learning is a form of e-learning that allows a learner to access educational resources and material any time anywhere (even when outside traditional learning places) using a mobile technology device. It is perceived that mobile learning mutated from e-learning, owing to the advent of an increasing mobile population, and the perceived limitations of other forms of conventional learning, distance education and e-learning (Mehdipour \& Zerehkafi, 2013).

\section{The Development and Augmentation for Mobile Learning Technologies in the World}

The demand for lifelong learning is rising at levels never seen before. In the early 1980s ICT technologies were being introduced in the school system. Scholars speculated that the technology would change the face of education. With well integrated ICT, educators came to appreciate the efficiency with which teachers were performing their duties. Education systems continued to receive support from the government and from the electronic industry to adopt the technology not only for administrative purposes but also for teaching and learning (Tapio, 2005). However despite the will and pressure, the furthest educational institutions went was introducing ICT as a school subject (Mugo, 2007). By the 1990s, the Internet gained widespread popularity, and began to transform culture and civilization in a manner never imagined. When the transfer of bulky data electronically became a reality, educators captured the niche by providing correspondence to distant learners not by post but via electronic mails, popularly known as emails (Lai, Stein, Field \& Pratt, 2016).

From the early 2000, delivery of learning content via electronic mail was improved by the emergence of Virtual Learning Environment. The virtual learning environment was possible through a specialized computer based program known as Learning Management Systems (LMS). The LMS were designed particularly to benefit college learners experiencing geographical, time or work related constraints. The LMS had the capacity to manage learning scenarios for learners with satisfaction (Solomon, 2013). Through e-learning, individuals began to achieve online academic qualifications while studying distances away from the university campus. However, eLearning had its inherent limitations. It required heavy upfront investment on desktop computers and required internet bandwidth. Desktop computers were expensive and bulky, and the cost of bandwidth was ecology of financially endowed institutions and rich individuals. Being heavy and bulky, desktop computers lacked portability and could not afford the flexibility greatly needed by the e-learning student. So when mobile technologies emerged, they appeared as technologies that could solve the challenges inherent in e-learning and other traditional pedagogies. With mobile technologies, educators saw a chance of designing instructional content and pedagogy around the mobile nature of the learner (Sharples, 2007).

Mobile learning therefore has emerged as one of the solutions to the challenges faced by education. With a variety of tools, resources and access to content any time anywhere, there are plenty of opportunities for formal and informal learning, both inside and outside the classroom (Mehdipour \& Zerehkafi, 2013). First, UNESCO (2009) observed that mobile technologies can be an opportunity to leverage existing technological uptake by educational institutions, owing to the cost benefits over computers and over other technologies associated with tethered learning. Another augment for mobile technologies is the opportunity the technology provides in encouraging lifelong learning. The technologies provide learners with increased access to learning opportunities in nontraditional settings (UNESCO, 2009). Mobile technologies are attractive and affordable, providing great potential for reaching marginalized groups, providing opportunities for learning and development. In situations where access to education is a challenge (due to geographical location, conflict or due to disaster), mobile technologies come 
in handy to provide access (Mehdipour \& Zerehkafi, 2013). Thirdly, the widespread ownership of mobile devices and familiarity that users have with the devices has immeasurable benefits. The cost of connectivity, equipment overlay, as well as expenditure for training faculty and students is considerably reduced (UNESCO, 2009).

Various other benefits have been cited by a number of scholars. Crescente and Lee (2011, as cited in Mehdipour \& Zerehkafi, 2013), observe that mobile technologies are better for learning because they are more lightweight than books and personal computers (PCs), and can be useful tools for students with special needs. Likewise, the excitement with which young adults have accepted the mobile technology can be a cause for improving levels of literacy and participation in education scenarios amongst young adults. Adding to the debate, El-Hussein (2010) and Behera (2013) reiterates that the storage capability of the mobile devices presents great advantages to their users. The internal and external memory of the mobile devices can be used to save data which is then transferred to other users of the device. In this way the learner and their instructors can exchange data, gaining considerable knowledge and experiences. Another notable advantage of mobile learning is that more of m-learning programs are aimed to benefit older learners, chiefly because they have jobs and engagements that make it difficult to attend learning in a traditional setup (UNESCO, 2011).

\section{Attitude towards Instructional Technologies}

An understanding of students' and teachers attitudes towards technology is necessary and a prerequisite to effective teaching with the technology. Seeing the enthusiasm with which schools and universities around the world are investing time and money with instructional technologies, the attitude of teachers and students towards educational technology has attracted close investigations (McLeod, 2007). A study conducted by Loyd (1984) demonstrated that a general positive attitude towards learning has a great potential for academic success. On the contrary, negative attitude towards learning makes academic success less likely. These observations can also be extrapolated to attitude towards instructional technologies.

Tai and Ting (2011) conducted a study in Taiwan, which appears to be a good reference for other contexts that wish to adopt and implement mobile technologies. The results showed the significant roles of the teacher and students in explaining how to utilize technology in pedagogy. Fundamentally, teachers and students must have an attitude that the technology is easy to use, has a pedagogical advantage and can solve workload challenges. It follows that designers of mobile learning programs must first improve teacher and students' perception by engaging them with hands on experiences, during which technical challenges, workload issues and pedagogical potentials are addressed. Since the attitude of Kenyan university students towards mobile technologies has not been measured, a study to document and propose the meaning of their attitude against an established technological acceptance models is necessary.

\section{The Conceptual Framework}

Figure 1 represents a conceptualization of a framework and assumes that the dependent variable "technological utilization" is a function of independent variables. The independent variables included student related factors such as age, gender, the devices they own, their preferred service provider, proficiency, frequency of use, and attitude. In the literature, the variables have been found to influence the success or failure of any technology programs in the school setting. The independent variables interact seamlessly to influence technological utilization during the teaching learning process.

\section{METHODS}

\section{Design}

The design adopted for the study was descriptive survey. Questionnaires were administered to a sample of individuals, who were representative of the population. The data gathered was classified, analyzed, compared, interpreted and generalized. From the generalizations, important principles and knowledge were formulated (Kombo \& Tromp, 2006).

\section{The Study Location}

The study was conducted in chartered public and private universities in Kenya. Only universities located from the

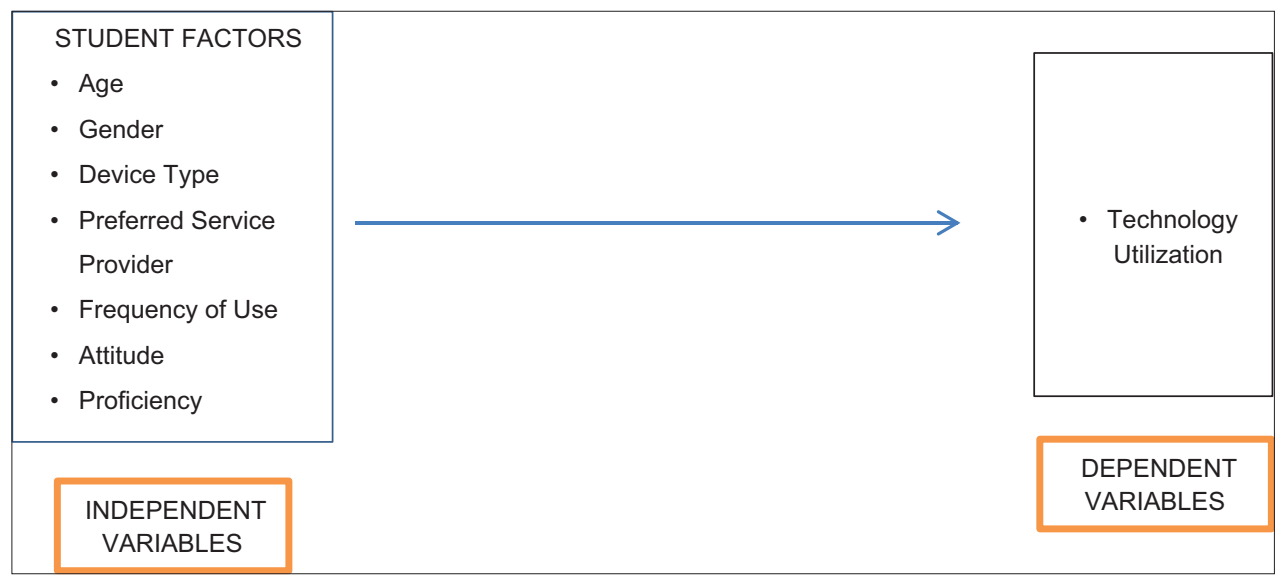

Figure 1. A conceptual framework for the adoption and utilization of Mobile technologies 
intersection of State House road with Uhuru Highway in Nairobi, branching off at Museum Hill interchange, extending into Forest Road, and then stretching along the Great North Road coded as road A2. All chartered universities falling along or off this road but are within Nairobi and the Nyeri counties, Kenya were included in the study.

\section{The Study Population}

The population in this study constituted of regular third year undergraduate students in Kenyan universities. The targeted population was third year regular university students of chartered universities within Nairobi and Nyeri Counties in Kenya. A total of 30,752 regular third year undergraduate students constituted the target population. The accessible population was 13,861 third year university students.

\section{Sampling}

Universities to participate in the study were divided into two (2) strata: public universities and private universities. In the first strata, University of Nairobi and Dedan Kimathi University of Technology were sampled. In the second strata, United States International University and KCA University were selected. Three (3) schools, whose students would participate in the study were selected from each university.

The sample size for the respondents was obtained based on the Krejcie and Morgan (1970) table (Guthrie, 2010; Morgan, 1990; Neuman, 2008; Nganga et al., 2009; Zina, 2007). According to Zina (2007), since the accessible population was 13,861 third year students, then based on the Krejcie and Morgan table, an approximate sample size of 375 respondents were considered. The 375 students were distributed across the selected universities in proportion to the population.

\section{Research Instruments}

A questionnaire was used as the main tool for collection of data. It had a variety of items, from which respondents read and filled their responses. The questionnaire had 4 sections: section 1 obtained data on the personal characteristics about the respondents; section 2 informed on the characteristics on mobile devices owned by the respondents; while section 3 obtained data related to their level of utilization of mobile technologies. A 5-point Likert scale was used to determine the level of utilization of the technologies. The response categories were as follows; (1) Never at all, (2) 1-3 times, (3) 4-6 times, (4) 7-9 times, (5) 10 and above. Section 4 obtained data related to the attitude of students towards mobile devices.

\section{Pilot Study, Validity and Reliability}

\section{Pilot study}

To determine the reliability, validity and practicability of the research instruments were determined by the pilot study. Kabarak University was purposively selected as the pilot institution. Thirty (30) third year students were selected for piloting.

\section{Validity}

Achievement of validity of the research instruments was attempted at the stage of data collection, data analysis as well as interpretation. Threats to validity of instruments at the design stage were minimized by ensuring readability levels were appropriate (Cohen, 2010). Face validity of the questions was achieved by asking experts to make a judgment if, on the face value, the items in the instruments reflected on the research concept with satisfaction.

\section{Reliability}

In the study, consistency (reliability coefficient) of instruments $(\alpha)$ was estimated using the Cronbach alpha formula. Using this method, the test instruments were run once using the split half method. The items in the instruments were divided into two halves, based on an odd-even number basis. Data from each half was analyzed separately. Theoretically it was expected that the values be equal and/or greater than 0.7 . The alpha value for the first half was 0.82 , while the second half was 0.77 . Both values exceeded the theoretical 0.7 and had a small range between them. This indicated the instrument was reliable in measuring the indicated constructs.

\section{Data Collection Procedures}

Before collecting data, a letter of authorization was obtained from the Institute of Postgraduate Studies and Research, Kabarak University. The letter was forwarded to the National Council for Science, Technology and Innovation (NACOSTI), who gave a research permit. Consent to collect data was granted by the Education Officer and County Commissioner for Nairobi and Nyeri Counties. Likewise consent was provided by the Deputy Vice Chancellor (Research and Innovation) for each of the selected universities, and from the Dean of the selected school. Then the researchers met and created rapport with the students, and on the same day concurred on the most appropriate date for data collection (Orina, 2000). On the date of data collection, the researchers visited the students and requested them to fill and return the questionnaires.

\section{DATA ANALSYIS AND INTERPRETATION}

After organizing and coding, the data was fed it into the Statistical Package for Social Sciences (SPSS) version 20.0 for the purpose of analysis. Likert scales were used to manage ordinal data; while descriptive statistics were used to manage quantitative data. Measures of dispersion were used to compliment results obtained from statistical treatments (Zina, 2007).

During data analysis, the main independent variable that influences the use of mobile technologies: - student related factors was examined. The characteristics of the devices owned, student proficiency, levels of technology utilization and attitude of students towards mobile technologies were examined. The main dependent variable was technological adoption whose outcomes were indicators such as positive 
learning outcomes, increased access to course material, as well as flexibility and convenience of learning.

\section{Response Rates}

Out of the expected 375 respondents, 302 questionnaires were completed and returned. This represented a response rate of $80.53 \%(n=302)$. According to Mangione (1995) in Bryman (2012), a response band of $70-85 \%$ and above is satisfactorily a good output, and confers to the researchers' minimal non-response bias. The response rate was therefore deemed acceptable for the study.

\section{RESULTS}

\section{Mobile Devices Owned by Students}

In this section the researchers sought to find out the category of mobile devices that respondents owned. While multiple device ownership was augmented, the output indicated that the Smart Phone and Laptop were the most popular mobile devices. Ownership rates of the devices stood at $85.8 \%$ $(n=259)$ and $57.0 \%(n=172)$ for Smart Phone and laptops respectively as shown on Table 1:

Personal Digital Assistants (PDAs), Satellite Phones and Feature Phones were yet to receive sufficient popularity amongst the respondents. By design, PDAs are heavy and bulky, most designed to provide solutions to specific categories of the working class. By extension, such devices could not be attractive amongst university students.

The ownership of satellite phones stood at only 3.0\% $(n=9)$. This rate were considerably lower than that of the Laptop 57.0\% $(n=172)$, Smart Phone $85.8 \%(n=259)$ and Tablets $8.9 \%(n=27)$. Literature holds similar arguments and tries to give meaning to the low frequency of satellite phones in the general population (Patti, 2005). Chandler (n.d) gives meaning to these findings by augmenting that the low frequency of Satellite phones in the general population is because they are designed for specialised usage, the devices are more popular in remote places, sparsely populated regions of the earth, areas where terrestrial communication systems are unavailable or have broken down. They come in handy in locations where governments restrict the access of cell and internet communication. Though more resilient than other mobile devices, the satellite phones are heavy, bulky and quite expensive to use for voice and data communication. This makes them less popular amongst the students.

The results further indicated an equally low ownership rate of feature phones standing at 7.6\% $(n=23)$. Jansen (2014) similarly observed low ownership rates for Feature Phones in the general population. Feature phones are phones with low processing capacity, limited memory and are designed to perform phone calls, Short Message Services (SMS) and nothing more (IDC, 2016). They are relatively affordable but have limited processing capacity but lack advanced multimedia and connectivity options. The inability of the phones to provide internet connectivity was assumed to make them appear too lacking to receive acceptance by the student fraternity.
Smart Phones $85.8 \%(n=259)$ were the most popular amongst the students. This is because the devices possess several features that make them readily acceptable. Key among the features is the fully-fledged computer capability and their inherently sleek design. Rafael, Michael and Jennifer (2005) posit that Smart Phones can run programs and games, access the internet, send email, make voice calls, post video calls, browse the web, take photos, navigate with the inbuilt Global positioning service (GPS) application, manage contacts and appointments. Though more expensive than standard feature phones or a PDA, Smart Phones are more fashionable, attractive and versatile enough to receive acceptance by an average university student.

\section{Mobile Device Brands Owned by Respondents}

There are many manufacturers of mobile devices. So the respondents were asked to indicate the brand name of the device that they owned. The output appears as indicated in Figure 2:

Output from Figure 2 provides an impression that Tecno is the most popular of all device brands, with a percentage ownership rate of $32.5 \%(n=98)$. This popularity can be attributed to the specific features about the brand: it has a pleasant face, amusing colors, sleek design and numerous applications. Samsung comes second in popularity, with a $30.1 \%(n=91)$ ownership rates. This can be attributed to the equally attractive features, but their pricing is rather prohibitive to this segment of respondents. Motorola and Alcatel ownership rates stood at $12.9 \%(n=39)$ and $6.3 \%(n=19)$ respectively. The two brands are struggling to make an impression in the era of smart handsets. Nokia though popular in the

Table 1. Mobile devices owned ( $\mathrm{N}=302)$

\begin{tabular}{lcc}
\hline $\begin{array}{l}\text { Respondent } \\
\text { category }\end{array}$ & Number of users & Percentage \\
\hline Laptop & 172 & 57.0 \\
Tablet & 27 & 8.9 \\
Smart phones & 259 & 85.8 \\
Feature phone & 23 & 7.6 \\
Satellite phone & 9 & 3.0 \\
PDA & 4 & 1.3 \\
\hline
\end{tabular}

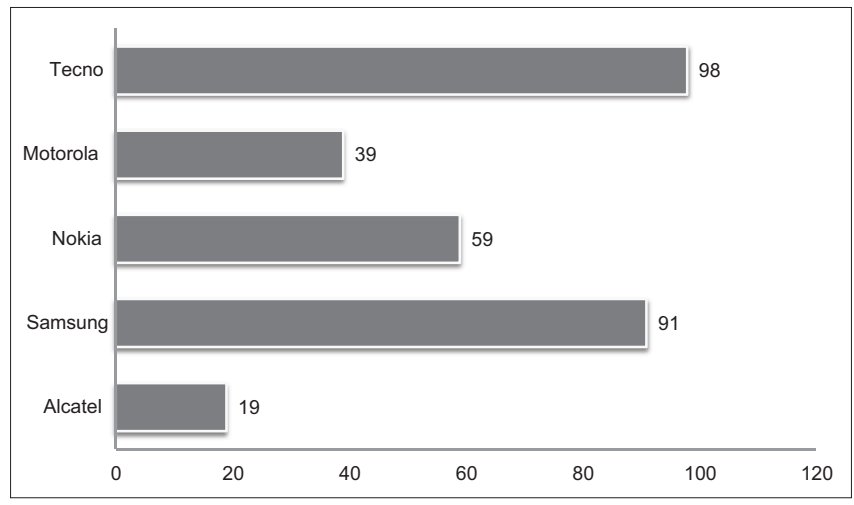

Figure 2. Mobile Brand Owned by Student Respondents 
era of feature phones has since shut down the production of new handsets. The findings of this study are consistent with the arguments of Zab (2015) who posited that device manufacturers are now keen on launching only those devices that pose effective challenge to the dominance of incumbents.

\section{Telephone Service Provider (s)}

When asked to indicate their preferred service provider, 95.7\% $(n=289)$ of the respondents indicated subscription to Safaricom, while Airtel and Telecom-Orange posted 25.8\% $(n=78)$ and $11.6 \%(n=35)$ respectively. Due to its elaborate marketing strategy and superior applications, Safaricom appeared to have had a dominant preference by the respondents. These observations can be corroborated by the Communication Authority of Kenya quarterly sector statistical report for January March 2015. The report singled Safaricom as the dominant player with a market base of $66.3 \%$ and a revenue share of $90 \%$. AirTel market share stood of $20.2 \%$ and Telecom Orange at $10.3 \%$ (Communication Authority of Kenya: 2015). Though the report indicates a new entrant referred as Finserve Africa Limited (who operates under the brand Equitel) and whose market share stood at $1.9 \%$ at the time of data collection, none of the respondent had subscribed to this provider. Figure 3 is a graphical representation of the outputs obtained after data was run on SPSS.

\section{Preferred Communication Standard Speed}

When asked to identify the standard communication speed for their portable devices, students respondents indicated that $44.4 \%(n=134)$ possess devices that can access data using $3 \mathrm{G}$ technologies, $25.5 \%(n=77)$ and $12.3 \%(n=39)$ on $4 \mathrm{G}$. The reason for this observation is that devices supporting the $3 \mathrm{G}$ technologies are more affordable to the student population. Besides handsets supporting $3 \mathrm{G}$ technology are able to support services ranging from voice, text, data and rapid access to the internet from their service provider. However, since the technology is slower than the $4 \mathrm{G}$ technologies, a small percentage of the student population [(25.5\%) $(n=77)]$ was migrating to the more versatile technology. Since network providers are yet to roll out the $4 \mathrm{G}$ network on a larger scale, buyers find no need of investing heavily on handsets and SIM cards that can support the $4 \mathrm{G}$ technology. This Information is summarized in Figure 4.

\section{Subscribers' Tariff}

Respondents were asked to indicate the tariff to which they had subscribed. Prepay tariff is a tariff in which a subscriber purchase air or data credit and loads it on the mobile device before accessing any product or service from the service provider. On the other hand, a post pay service is a tariff which allows a subscriber to use a service for which they pay after consuming the service. The latter is more popular amongst corporate customers, business and affluent members of the society. The former allows the subscriber to use credit according to their ability, and was noted to be more popular amongst the students. $83.1 \%(n=251)$ are subscribers to prepay tariff, against $14.2 \%(n=43)$ for the post pay tariff. The results re-

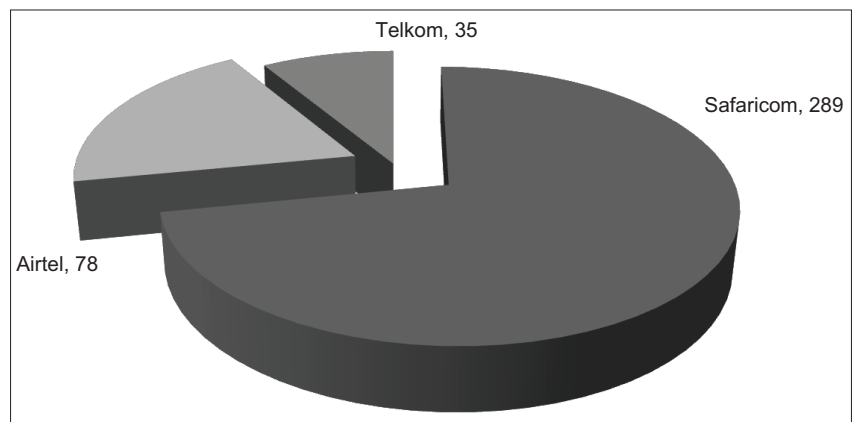

Figure 3. Frequencies of Preferred Service Provider by Students

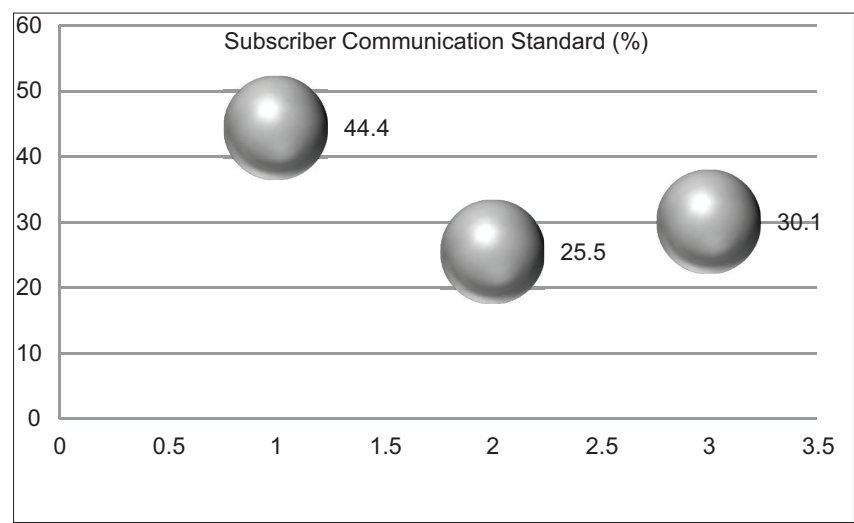

Figure 4. Percentage of Preferred Subscriber's Communication Standard

vealed inconsistency with operator returns results obtained from the Communication Authority of Kenya Statistical report (2015), who observed that out of the 34,794,457 subscribers in Kenya, 937,043 are postpaid customers, while the rest $33,857,414$ are prepaid subscribers. This translates to $97.31 \%$ and $2.69 \%$ for prepay and post pay subscribers respectively.

\section{Category of Device Keyboard}

Respondents were asked to identify the keyboard mounted on their devices. The most popular of all the keyboard categories is the touch keyboard standing at $44.4 \%(n=134)$. The standard keyboard (such as that mounted on a feature phone) had the lowest frequency of $25.5 \%(n=77)$. For phone users who need to email, surf the internet, or share text data over social media, a standard keyboard would be time consuming. This is because the user may be required to press keys multiple times before they can obtain the desired character. Therefore the popularity of QWERTY and touch keyboards following the full QWERTY format can provide accuracy during input, is user friendly and less tiring. The touch keyboard is particularly popular since the keys do not wear out, thereby the cost of replacement, and loss of aesthetic value to tear and wear is considerably low.

\section{Respondents' Device Operating System}

The researchers sought to find out the operating systems installed in respondents' mobile devices. $80.8 \%(n=244)$ of the 
respondents indicated that their devices run on Android operating system. Nicholos (2014) argues that Android is perceived to possess superior aesthetic features. Further devices that run on the operating system are ideal because they support many mobile applications, are significantly efficient and beautiful in appearance. Besides most of the Smart Phone brands possessed by students such as Tecno and Samsung, run on Android. The global statistics for Android, Windows Phone and Apple IOS, stands at 75\%, 10.1\% and 2.8\% respectively (Zab, 2015). Therefore the global statistics collates strongly with the findings of this study. The data obtained from the study are represented in Figure 5.

Several arguments can be made based on the observations on Figure 5. The first regards the Apple Operating System, which registered the least frequency amongst respondents 2.8\% ( $n=9)$. Divya and Kumar (2014) echoes the findings of this study and arguments that Apple iOS is designed specifically for iPhones, iPods and iPads (the most expensive of all mobile devices). On the other hand Symbian is an operating system developed for Nokia handsets. With the loss of popularity of the Nokia brand in the Kenyan market, the preference of the operating system by students' users was quite low [(6.3\%) $(n=20)]$. Windows Operating System, though colorful and user friendly, mobile phone users find it quite challenging to use. The brand, made by Microsoft and popular in the computing world may be popular with older users but not with the younger generation (Renner, 2013). Hence a $10.1 \%(n=32)$ frequency amongst university students can be justified. Android attracted a $75.0 \%(n=237)$ response rate amongst students. It's popular because it is an open source operating system that allows the user to install third-party applications. Other reasons for popularity as sited by Divya and Kumar (2014) were adopted for this study and revolve around their ability to support thousands of applications, applications that give users the freedom to use their devices for video calls, phone calls, instant messaging, mapping, browsing, ticket booking and for accessing useful curricular material.

\section{Levels of Utilization of Devices}

In this section the levels of utilization of mobile technologies by university students was examined. To achieve this objective, it was necessary first to determine the academic applications installed in the mobile device of the respondents. Having determined that, the researchers then proceeded to make the necessary determinations.

Over the last five years several academic applications have been created. The need for the applications in academia is to source for academic material, to share classroom material, to create, edit and share documents, and for retrieval of files from servers that host vital academic material. Online dictionaries, Global Positioning System and Social Academic blogs were of particular interest to the study. The apps are useful for searching general information, navigation to remote or unfamiliar locations and social academic networking. Other academic mobile applications were not considered in this study. This variable registered the output as indicated in Table 2.

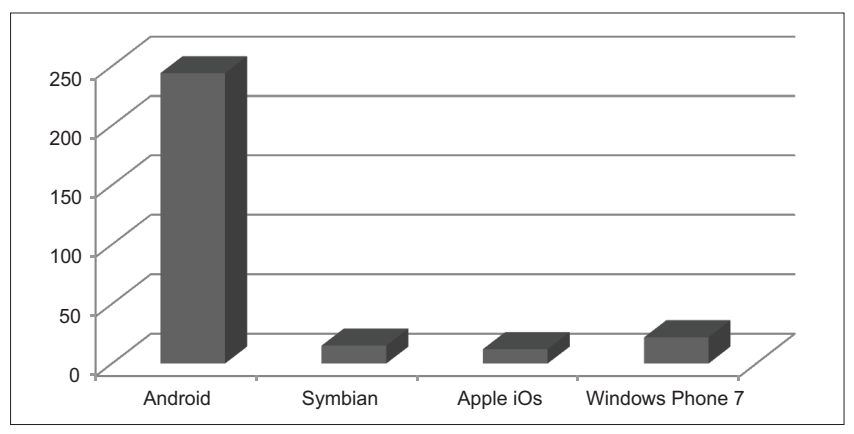

Figure 5. Frequency of operating systems

Table 2. Academic application installed in students devicess

\begin{tabular}{lcc}
\hline $\begin{array}{l}\text { Respondent } \\
\text { category }\end{array}$ & $\begin{array}{l}\text { Number } \\
\text { of users }\end{array}$ & Percentage \\
\hline Dictionaries & 179 & 59.3 \\
GPS & 126 & 41.7 \\
Social academic blogs & 92 & 30.5 \\
\hline
\end{tabular}

The respondents demonstrated considerable use of online dictionary and GPS systems 59.3\% $(n=179)$ and $41.7 \%$ $(n=126)$ respectively. Social academic blogs registered a response rate of $30.5 \%(n=92)$. These findings corroborates the arguments of Dunleavy (2015) in Greens (2015) who appreciates that blogging can be a great way of building up knowledge, growing readership, and establishing meaningful public conversation, but its uptake in academic circles is lacking.

Scholars investigating the use of online dictionaries provide insights that relate to the finding obtained in this study. Online dictionaries have been argued as an emerging tool that valuably scaffolds the learning of a foreign language. Li and Deifell (2013) in their studies on student perceptions of online dictionaries in the United States of America (particularly those that can be accessed via websites or mobile device applications) indicated that $87.5 \%$ of respondents download and frequently use online dictionaries for their academic purposes. This variable indicated a 59.3\% $(n=179)$ usage, indicating serious inconsistencies with literature.

\section{Academic Duties Performed Using Mobile Devices}

The respondents were requested to indicate the academic duties that they perform with their mobile devices. From the results obtained, email was the most popular with a response rate $79.4 \%(n=251)$. Collaboration with students from other world's universities and participation to online blogs for academic purposes stood at $10.6 \%(n=32)$ and $20.9 \%(n=63)$ respectively. Though online blogs are popular in the nonacademic circles, university students who participated in the survey are yet to know how the facility can be useful for academic purposes. This is in line with the findings of Mishra and Koehler (2009), Dunleavy (2015) who advances that blogging, has not been accepted fully as an educational technology.

The study further confirms that the most outstanding service under this variable is email. Email use amongst re- 
spondents posted $84.8 \%(n=256)$. Email has been considered quite useful as a tool for communication. Earlier studies done in the United Stated of America (USA), with a view of investigating email use amongst university students, posted similar results. While discussing the results of the study, Johnson et al, (2008) in Gao, Zhao and McJuckin (2015) equated the popularity of email to its convenience and affordability. Being an asynchronous channel of communication, email is argued to provide to the learner opportunities to receive psychosocial support, and a convenient way of communicating with professors, classmates and friends in situations where phone call conversations would be limiting.

An encouraging observation is that $63.6 \%(n=192)$ of the respondents agreed to be actively engaged in making reference to online material in their area of specialization. This is in line with the augmentation of Sahin, Balta and Ercan (2010), who posited that when university students have opportunity, they prefer to use internet resources over classical libraries. Besides many universities' teaching staffs publish their course material on the cyber space, after which students are free to access the material by downloading from the net. The study demonstrates that students are making adequate use online reference material. Other academic duties performed using mobile devices include reading of e-books $54.3 \%(n=164)$, reference to online encyclopedia $(44.4 \%$, $n=134$ ), and collaboration with students from other universities $(10.6 \%, n=32)$.

\section{Frequency of Use of Mobile Devices}

Respondents were asked to indicate the frequency of use of applications on their mobile devices. Their responses were rated on a five (5) point Likert scale of never at all, 1-3 times, 4-6 times, 7-9 times then 10 and above. Table 3 indicates the output obtained from respondents.

The results obtained on this variable indicate that watching TV and access of academic material over skype was the least utilized service. The two services attracted a never at all response of $68.5 \%(n=207), 62.6 \%(n=189)$ respectively. Some reasons for these observations can be suggested: that watching television, and exchanging academic material over skype, though available on the student mobile device can be quite demanding on data bundles and battery. Sending text messages, taking photos, sending and receiving of email and making a voice call were the most popular services standing at $58.99 \%(n=178), 29.1 \%(n=88), 29.1 \%(n=88)$ and $28.8 \%(n=87)$ respectively. Nevertheless, the variable recorded frequencies that were below average, and therefore their popularity cannot be underscored. Despite this fact, it was established that students prefer short message services over voice call. The cost of an average voice call across all networks is relatively higher than that of a short text service. The preference of this service amongst students can thus be justified. Besides, the respondents belonged to a segment of the population that has sufficient proficiency in manipulating the keyboard on their mobile device. Further, being regularly in for lectures, tutorial, laboratory work or in for a library engagement, responding to a voice call can be seen as nuisance and disturbing. For this reason, students find short message communication to be most convenient. Nonyongo, Mabusela and Monene (2006), carried out a similar study regarding the effectiveness of SMS communication between university and students at the University of South Africa (UNISA). Their study was able to demonstrate that university students find SMS communication a convenient way for accessing vital information regarding assignment dates, tutorial support, pre-examination information and registration. Though the authors argue that SMS frequency can be costly to the institution when done frequently, a twice or thrice a semester communication could prove feasible and cost effective. Though SMS has been a popular method of communication, newer mobile applications such as WhatsApp and Instagram, which allows the exchange of still and motion graphics are emerging (Communication Authority of Kenya, 2015; Lazzari, Caso and De Fiori, 2016).

This study sought to investigate the frequency with which respondents utilize mobile devices for academic purposes. The variables associated with this objective include the frequency of accessing learning content; upload of course material, download of courseware, type course assignment and printing the typed documents. The researchers treated never at all and 1-3 times as less frequent, while 7-9 times and 10 and above times as more frequent. Respondents falling on the borderline were assumed to be average users of this service. So when measured against a six (6) point Likert scale, the observation was that $58.6 \%(n=177)$ of the respondents were not using their devices in accessing learning content at all at all. On the contrary $41.4 \%(n=125)$ were accessing course material from their devices. This observation indicates that the devices are frequently used for non-academic obligations, but rarely utilized for academic purposes.

The study was also able to establish that $70.2 \%(n=212)$ of the respondents do not use their devices at all for the purpose of uploading course material. Similar frequencies were observed regarding downloading of courseware. $60.6 \%(n=183)$ of the respondents indicated that they hardly use the devices to download course material. In theory, limited use of a technology can be attributed not to its complexity but due to inherent technical limitations. Stockwells (2010) in Daesang, Kim and Seo (2013) in their study on the perception and experiences of mobile learning, indicated that the usability and willingness of users to utilize mobile technologies for learning is to a great extent dependent on the inherent technical limitations that the devices portends - a small screen, a limiting keyboard... and limited battery life. Other studies by Suki and Suki (2009) supports that the keypad, screen resolution, and the screen size are too small to allow easy navigation of the mobile device graphical user interface.

Students were asked to indicate the frequency with which they performed the indicated academic duties per day. Table 4 is a summary of the output obtained when data was run on SPSS. The frequencies were measured on a five (5) point Likert scale of never at all (0), 1-3 times, 4-6 times, 7-9 times and 10 and above time.

For the purpose of data interpretation, non-response, never at all and 1-3 times were treated as infrequent while 4-6 times, 7-9 times and 10 and above times were treated as frequent. $73.8 \%(n=223)$ of the respondents indicated infre- 
Table 3. Frequency of use of applications on student's mobile devices

\begin{tabular}{|c|c|c|c|c|c|c|c|c|}
\hline S.No & Item & $\mathbf{N}$ & Never & 1-3 times & 4-5 times & $7-9$ times & $\begin{array}{l}10 \text { or more } \\
\text { times }\end{array}$ & $\begin{array}{c}\text { Non } \\
\text { response }\end{array}$ \\
\hline 1. & Make a voice call & 302 & $49(16.2 \%)$ & $67(22.2 \%)$ & $58(19.2 \%)$ & $35(11.6 \%)$ & $87(28.8 \%)$ & $6(2.0 \%)$ \\
\hline 2. & Send a text message & 302 & $9(3.0 \%)$ & $32(10.6 \%)$ & $43(14.2 \%)$ & $34(11.3 \%)$ & $178(58.9 \%)$ & $6(2.0 \%)$ \\
\hline 3. & $\begin{array}{l}\text { Send money to an } \\
\text { individual }\end{array}$ & 302 & $83(27.5 \%)$ & $129(42.7 \%)$ & $31(10.3 \%)$ & $20(6.6 \%)$ & $25(8.3 \%)$ & $14(4.6 \%)$ \\
\hline 4. & $\begin{array}{l}\text { Withdraw money } \\
\text { from bank }\end{array}$ & 302 & $110(36.4 \%)$ & $101(33.4 \%)$ & $38(12.58 \%)$ & $22(7.3 \%)$ & $16(5.3 \%)$ & $15(5.0 \%)$ \\
\hline 5. & Pay bill & 302 & $115(38.1 \%)$ & $95(31.5 \%)$ & $44(14.6 \%)$ & $14(4.6 \%)$ & $18(6.0 \%)$ & $16(5.3 \%)$ \\
\hline 6. & Purchase airtime & 302 & $36(11.9 \%)$ & $93(30.8 \%)$ & $56(18.5 \%)$ & $37(12.3 \%)$ & $71(23.4 \%)$ & $9(3.0 \%)$ \\
\hline 7. & $\begin{array}{l}\text { Purchase air } \\
\text { bundles }\end{array}$ & 302 & $33(10.9 \%)$ & $94(31.1 \%)$ & $55(18.2 \%)$ & $32(10.6 \%)$ & $78(25.8 \%)$ & $10(3.3 \%)$ \\
\hline 8. & $\begin{array}{l}\text { Access learning } \\
\text { content }\end{array}$ & 302 & $24(7.9 \%)$ & $79(26.2 \%)$ & $74(24.5 \%)$ & $50(16.6 \%)$ & $63(20.9 \%)$ & $12(4.0 \%)$ \\
\hline 9. & $\begin{array}{l}\text { Upload course } \\
\text { material }\end{array}$ & 302 & $86(28.5 \%)$ & $91(30.1 \%)$ & $35(11.6 \%)$ & $29(9.6 \%)$ & $43(14.2 \%)$ & $18(6.0 \%)$ \\
\hline 10. & $\begin{array}{l}\text { Download course } \\
\text { material }\end{array}$ & 302 & $34(11.3 \%)$ & $101(33.4 \%)$ & $48(15.9 \%)$ & $38(12.6 \%)$ & $68(68 \%)$ & $13(4.3 \%)$ \\
\hline 11. & Send an email & 302 & $36(11.9 \%)$ & $93(30.8 \%)$ & $55(18.2 \%)$ & $42(13.9 \%)$ & $68(68 \%)$ & $8(2.6 \%)$ \\
\hline 12. & Receive an email & 302 & $38(12.58 \%)$ & $74(24.5 \%)$ & $50(16.6 \%)$ & $41(13.6 \%)$ & $88(29.1 \%)$ & $11(3.6 \%)$ \\
\hline 13. & $\begin{array}{l}\text { Send/receive a } \\
\text { twitter post }\end{array}$ & 302 & $118(39.1 \%)$ & $45(14.9 \%)$ & $30(9.9 \%)$ & $36(11.9 \%)$ & $56(18.5 \%)$ & $17(5.6 \%)$ \\
\hline 14. & $\begin{array}{l}\text { Send/receive } \\
\text { facebook post }\end{array}$ & 302 & $86(28.5 \%)$ & $60(19.9 \%)$ & $41(13.6 \%)$ & $37(12.3 \%)$ & $62(20.5 \%)$ & $16(5.3 \%)$ \\
\hline 15. & Skype & 302 & $189(62.6 \%)$ & $50(16.6 \%)$ & $14(4.6 \%)$ & $7(2.3 \%)$ & $17(5.6 \%)$ & $25(8.3 \%)$ \\
\hline 16. & Watch a movie & 302 & $141(46.7 \%)$ & $67(22.2 \%)$ & $34(11.3 \%)$ & $24(7.9 \%)$ & $23(7.6 \%)$ & $13(4.3 \%)$ \\
\hline 17. & Take a photo & 302 & $36(11.9 \%)$ & $78(25.8 \%)$ & $56(18.5 \%)$ & $32(10.6 \%)$ & $88(29.1 \%)$ & $12(4.0 \%)$ \\
\hline 18. & Print a document & 302 & $148(49.0 \%)$ & $71(23.5 \%)$ & $33(10.9 \%)$ & $14(4.6 \%)$ & $19(6.3 \%)$ & $17(5.6 \%)$ \\
\hline 19. & $\begin{array}{l}\text { Type a course } \\
\text { assignment }\end{array}$ & 302 & $112(37.1 \%)$ & $80(26.5 \%)$ & $42(13.9 \%)$ & $24(7.9 \%)$ & $32(10.6 \%)$ & $12(4.0 \%)$ \\
\hline 20. & Listen to a radio & 302 & $110(36.4 \%)$ & $78(25.8 \%)$ & $44(14.6 \%)$ & $24(7.9 \%)$ & $31(10.3 \%)$ & $15(5.0 \%)$ \\
\hline 21. & Watch TV & 302 & $207(68.5 \%)$ & $33(10.9 \%)$ & $21(7.0 \%)$ & $11(3.6 \%)$ & $10(3.3 \%)$ & $20(6.6 \%)$ \\
\hline
\end{tabular}

Table 4. Frequency of use of mobile devices for academic purposes

\begin{tabular}{lccccc}
\hline Applications & \multicolumn{5}{c}{ Frequency of use } \\
\cline { 2 - 6 } & \multicolumn{5}{c}{ Frequency (\%) } \\
\cline { 2 - 6 } & Never at all & $\mathbf{1 - 3}$ times & 4-6 times & 7-9 times & 10 and above \\
\hline Access learning content & $42(13.9)$ & $79(26.1)$ & $74(24.5)$ & $50(16.6)$ & $63(20.9)$ \\
Upload course material & $104(34.4)$ & $91(30.1)$ & $35(11.6)$ & $29(9.6)$ & $43(14.2)$ \\
Download course material & $47(15.6)$ & $101(33.4)$ & $48(15.9)$ & $38(12.6)$ & $68(22.5)$ \\
Type a course assignment & $124(41.1)$ & $80(26.5)$ & $42(13.9)$ & $24(8.0)$ & $32(10.6)$ \\
Print a document & $139(46.0)$ & $74(24.5)$ & $36(11.9)$ & $18(6.0)$ & $25(8.2)$ \\
\hline
\end{tabular}

quent use of mobile device to print a document, while $67.6 \%$ $(n=204)$ of the respondents do not use their mobile device for typing their course assignment. Therefore, it can be deduced that respondents forward handwritten assignment to their lecturers and professors. These frequencies reveal that the use of devices to type assignment by students was far below average. Literature has research findings that show that the major reason why students find typing with mobile devices quite a challenge. For those students using the phone as their chief mobile device, the key pad is tiny and limiting. The students may find it a challenge transferring the typed material into another device when required to produce a paper copy of the assignment.

Further discussion can be obtained from Table 4: that though $32.5 \%(n=98)$ of the respondents said they frequently type course assignment using their devices, only $26.2 \%$ $(n=79)$ are able to print a document directly from their device. Except for those using laptops as the chief mobile device, 
users of PDA, tablets and Smart Phones have a challenge of interfacing the device with a printer. Most of the printers in the market at the period of study were normally connected to devices using a cable with capabilities to connect to a USB port. Few printers were able to allow the transfer of data using blue tooth or infra-red technologies. Such printers are more expensive, and not within the reach of an average university student. Since standard PDAs, Tablets and Smart Phones use micro USB type connectors, the devices cannot connect directly onto a computer, (unless configured to a wireless network and a wireless capable printer). Therefore, connecting such device to a printer for the purpose of printing becomes a real obstacle (Samsung electronics, 2014).

\section{Attitude towards Mobile Technologies}

In determining how student attitude impact on the uptake and utilization of mobile technologies for learning, a variable on attitude was included within the questionnaire. In designing instruments for measuring the attitudes of students towards mobile technologies, the researchers were guided by the Davis (1985) Technology Acceptance Model (TAM) (Venkatesh $\&$ Davis, 2000). So In this section the attitude of respondents on various attitudinal variables on mobile devices was interrogated. The measurement was done on a five point Likert scale of strongly disagree on one extreme and strongly agree on the other extreme. For the purpose of this discussion, no response, strongly disagree, disagree and neutral were treated as disagree, while agree and strongly agree were treated as agree Table 5 indicates the output obtained from this variable.

From Table 5 it was observed that $89.4 \%(n=270)$ respondents agreed that mobile devices are easy to use, $86.8 \%$ ( $n=262$ ) agreed that the technologies provide flexibility of the learning process, and $86.4 \%(n=261)$ accepted that the technology is a strong boost to information technologies. They further agreed that they'd encourage colleagues to source for learning material over their mobile devices. This variable attracted a $74.8 \%(n=226)$ response rate. However $49.7 \%$ $(n=150)$ of the respondents disagreed that courses in which learners use mobile devices are more interesting. On the other hand $54.6 \%(n=165)$ prefer the use of mobile technologies over other learning technologies. The response rates indicated a positive attitude of students towards the technologies. Earlier studies by Alharbi and Drew (2014) on the attitude of academics' behavioral intention to use a learning management system (LMS) in Saudi Arabia obtained similar findings that ease of use, and a positive attitude by user towards a technology is fundamental to its acceptance, adoption and utilization. In this study, since positive attitude towards the technologies was confirmed, then we can conclude that their acceptance will result to their utilization. Those students who utilize the technology will post better learning outcomes. Therefore the authors attest that "The necessity to use mobile technologies in education seems imperative and inevitable.

Table 5: Student attitude towards mobile technologies

\begin{tabular}{|c|c|c|c|c|c|c|c|c|}
\hline S.No & Item & $\mathbf{N}$ & $\begin{array}{l}\text { Strongly } \\
\text { disagree }\end{array}$ & Disagree & Neutral & Agree & $\begin{array}{l}\text { Strongly } \\
\text { agree }\end{array}$ & $\begin{array}{c}\text { Non } \\
\text { response }\end{array}$ \\
\hline 1. & $\begin{array}{l}\text { Mobile devices are easy to } \\
\text { use }\end{array}$ & 302 & $4(1.3 \%)$ & $2(0.7 \%)$ & $11(3.6 \%)$ & $88(29.1 \%)$ & $182(60.3 \%)$ & $15(5.0 \%)$ \\
\hline 2. & $\begin{array}{l}\text { Mobile devices provides } \\
\text { flexibility and convenience } \\
\text { of learning }\end{array}$ & 302 & $4(1.3 \%)$ & $6(2.0 \%)$ & $16(5.3 \%)$ & $92(30.5 \%)$ & $170(56.3 \%)$ & $14(4.6 \%)$ \\
\hline 3. & $\begin{array}{l}\text { Application on mobile } \\
\text { devices are useful for my } \\
\text { learning }\end{array}$ & 302 & $4(1.3 \%)$ & $5(1.7 \%)$ & $35(11.6 \%)$ & $90(29.8 \%)$ & $153(50.7 \%)$ & $15(5.0 \%)$ \\
\hline 4. & $\begin{array}{l}\text { Information from mobile } \\
\text { devices is current and useful }\end{array}$ & 302 & $3(1.0 \%)$ & $9(3.0 \%)$ & $30(9.9 \%)$ & $97(32.1 \%)$ & $148(49.0 \%)$ & $15(5.0 \%)$ \\
\hline 5. & $\begin{array}{l}\text { Courses that lecturers } \\
\text { incorporate mobilwe devices } \\
\text { are more interesting }\end{array}$ & 302 & $12(4.0 \%)$ & $28(9.3 \%)$ & $93(30.8 \%)$ & $71(23.5 \%)$ & $81(26.8 \%)$ & $17(5.6 \%)$ \\
\hline 6. & $\begin{array}{l}\text { Mobile devices can increase } \\
\text { learning opportunities to } \\
\text { marginalized groups }\end{array}$ & 302 & $6(2.0 \%)$ & $11(3.6 \%)$ & $36(11.9 \%)$ & $99(32.8 \%)$ & $135(44.7 \%)$ & $15(5.0 \%)$ \\
\hline 7. & $\begin{array}{l}\text { Mobile devices can offer } \\
\text { access to digital information } \\
\text { and hence boost information } \\
\text { technologies }\end{array}$ & 302 & $4(1.3 \%)$ & $6(2.0 \%)$ & $15(5.0 \%)$ & $88(29.1 \%)$ & $173(57.3 \%)$ & $16(5.3 \%)$ \\
\hline 8. & $\begin{array}{l}\text { I encourage my colleagues to } \\
\text { source for learning material } \\
\text { from mobile }\end{array}$ & 302 & $7(2.3 \%)$ & $14(4.6 \%)$ & $38(12.6 \%)$ & $99(32.8 \%)$ & $127(42.1 \%)$ & $17(5.6 \%)$ \\
\hline 9. & $\begin{array}{l}\text { I would prefer to use mobile } \\
\text { devices over other learning } \\
\text { technologies }\end{array}$ & 302 & $17(5.6 \%)$ & $27(8.9 \%)$ & $75(24.8 \%)$ & $72(23.8 \%)$ & $93(30.8 \%)$ & $18(6.0 \%)$ \\
\hline
\end{tabular}


Preparedness for using the technology in university education should be based on the concept of conviction and acceptance to use it in the teaching learning places."

\section{CONCLUSION}

Data was able to provide empirical evidence regarding devices owned students. It was concluded that the Smart Phone is the most popular mobile device amongst students. On the same vein, Tecno was the most preferred mobile handset amongst students. The QWERTY keyboard was more popular over any other keyboard type. The respondents prefer mobile devices running on Android operating systems. Safaricom was the dominant service provider amongst the student population. Students prefer prepay over prepay tariff, over the post pay tariff. This study established that the use of the devices for accessing teaching and learning content by students was considerably low. This compared unfavorably with the considerable higher levels of utilization of the devices for academic purposes. However, technologies are gaining considerable acceptance as tools useful for academic purposes.

After interrogating the attitude of students towards mobile technologies, the following conclusions were made: first, students have accepted that mobile technologies are easy to use, provide flexibility with learning experiences, and is a strong boost to information technologies. However, a sizeable number of students would prefer to use the technologies over other existing instructional technologies.

\section{Recommendations}

1) For effective adoption of mobile technologies in the university, students must undergo capacity building programs, with a view of empowering them on the modalities of making meaningful interaction with mobile based learning management systems. Such training should be frequent, with a view of building the confidence of students on how the technologies can increase their duty performance. The capacity building programs need be developed so as to incorporate theories and models of Technology Acceptance.

2) There is need to restructure educational sector policy with a view of shifting its orientation from provision of computer hardware to the provision of mobile computing. Related to this there is need to address the following challenges that hinder effectively utilization of mobile technologies: affordability of smart handsets, screen sizes, size of the keyboard, signal strength and service bandwidth.

\section{REFERENCES}

Alharbi, S., \& Drew, S. (2014). Using the Technology Acceptance Model in Understanding Academics' Behavioral Intention to Use Learning Management Systems. International Journal of Advanced Computer Science and Applications, 5, (1). Retrieved from www.ijacsa. thesai.org on $1^{\text {st }}$ September 2016.

Armatas, C., Holt, D., \& Rice (2005). Balancing the possibilities for mobile technologies in higher education.
Telstra Research Laboratories. Clayton: Teaching and Learning Support Unit, Learning Services, Deakin University, 27-35.

Baharom, S. S. (2013). Designing Mobile Learning Activities in Malaysian Higher Education Context: Asocial Constructivist Approach (Unpublished PhD thesis). Salford Business School, University of Salford, Salford, UK.

Behera, S. K. (2013). M-learning: a new learning paradigm. International Journal on New Trends in Education and their Implications, 4(2), 23-34. Retrieved on 16 June 2014 from http://www.ijonte.org

Bryman, A. (2012). Social Research Methods, $4^{\text {Th }}$ Edition. New York: Oxford University Press

Chen, B., \& Denoyelles, A. (2013). Exploring students' mobile learning practices in higher education. Retrieved from http://er.educause.edu/articles/2013/10/on $17^{\text {th }}$ July 2016

Cohen, L. et al. (2011). Research methods in Education, $7^{\text {th }}$ Edition. London: Routledge Publishers

Commission for University Education (2014). Universities Standards and Guidelines. Retrieved from www.CUE. ac.ke on $27^{\text {th }}$ July 2016

Communication Authority of Kenya (2015). Quarterly Sector Statistics Report. Third Quarter of the Financial Year 2014/15 (Jan-March 2015). Communication Authority. Retrieved from www.ca.go.ke/images/downloads/./\%20 Sector\%20 Statistics \% 20Q3\% 202014-2015, on $15^{\text {th }}$ July 2016

Daesang, K., Rueckert, D., Kim, D. J., \& Seo, D. (2013). Student perception and experiences with mobile learning. Journal of Language Learning and Technology, 17(13) 52-73

Divya, K., \& Kumar, V.K. (2016). Comparative Analysis of Smart Phone Operating Systems Android, Apple IOS and Windows. International Journal of Scientific Engineering and Applied Science (IJSEAS), 2(2), 432-439 Retrieved from www.ijseas.com on $15^{\text {th }}$ July 2016.

El-Hussein, M. O. M., \& Cronje, J. C. (2010). Defining Mobile Learning in the Higher Education Landscape. In Educational Technology \& Society, 13 (3), 12-21.

Gao, M., Zhao, H., \& McJunkin (2015). Email Use among International Students in a U.S. University. International Journal for Innovation Education and Research, 3 (12), 122-129

Green, D. (2015). An antidote to futility: Why academics should take social media seriously. Social Impact Blog. London, The London School of Economics and Political science. Retrieved from http://blogs.lse.ac.uk/impactofsocialsciences/2015/10/26/why-academics-and-students-should-take-blogging-social-media-seriously/on $12^{\text {th }}$ April 2016

Guthrie, G. (2010). Basic research methods: An entry to social science research. London: Sage Publications

Hosman, L., \& Fife, E. (2012). The Use of Mobile Phones for Development in Africa: Top-Down-Meets-BottomUp Partnering. Journal of community informatics, 8(3), $1-20$ 
Chau, M., et al (2017). IDC's Worldwide Mobile Phone Tracker Taxonomy, 2017. Framingham: IDC

Kandiri, J. M. (2014). Effective Implementation of Technology Innovations in Higher Education Institutions: A Survey of Selected Projects in African Universities. An unpublished PHD thesis submitted to the School of Business Kenyatta University.

Krejcie, R. V., \& Morgan, D. W. (1970). Determining Sample Size for Research Activities. Educational and Psychological Measurement

King, J. A. et al (1987). How to assess program implementation. Beverly Hills, California: Sage.

Kombo, D. K., Tromp, D. L. A. (2006). Proposal and thesis writing: An introduction. Nairobi: Pauline Publications Africa.

Lai,K., Stein, S., Field, P. and Pratt, K.(2016) Our World in Your Place 30 years of distance learning and teaching at the University of Otago. Distance Learning Office, University of Otago

Lazzari, M., Caso, L., \& De Fiori, A. (2016) Facebook and WhatsApp at school, present situation and prospects in Italy. Proceedings of the 13 th International Conference on Web Based Communities and Social Media 2016, Funchal, Portugal, July 1-2, 2016, pp. 233-236, ISBN 978-989-8533-54-8

Li, J., \& Deifell, E. (2013). Foreign Language Learners' Use and Perception of Online Dictionaries: A Survey Study. MERLOT Journal of Online Learning and Teaching 9(4), 515-532

Loyd, B., \& Gressard, C. (1984). "The effects of sex, age, and computer experience on computer attitudes." AEDS Journal 18(2): 67-77.

Mangione, T. W. (1995). Mail surveys: Improving the quality. Thousand Oaks, CA: Sage

Mark P., Maria, M., Gordon, J. (2013). The mobile economy. A.T. Kerney London; United Kingdom Retrieved from http://www.atkearney.com/documents/10 192/760890/TheMobile_Economy_2013. pdf; on $3^{\text {rd }}$ October 2014

Mberia, P. M., Ofafa G. A., Muathe, M. A., \& Muli, J. (2013). An empirical investigation on the relationship between technological infrastructure and government regulations on Effective operations of m-payment systems in Kenya. International Journal of Arts and Commerce ISSN 1929-7106. Retrieved from www.ijac.org. uk on 12-1-15

McLeod, J. K. (2007). Teachers' and students' self-reported attitudes toward technology: A literature review. Retrieved from http://www.juliemcleod.org/portfolio/pdfs/ attitudes_lit_review.pdf on $8^{\text {th }}$ January 2015

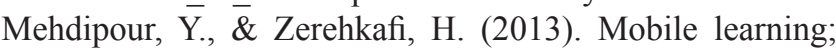 benefits and challenges. International Journal of Computational Engineering Research, Vol 03, Issue 6.

Mishra, P., \& Koehler, M. (2009). Too Cool for School? No Way! Using the TPACK Framework: You Can Have Your Hot Tools and Teach with Them, Too. Learning \& Leading with Technology,36 (7), 14-18. Retrieved from http://www.fullerton.edu/technologyservices/_resources/pdfs/SC10SemerLitReview.pdf on $15^{\text {th }}$ April 2016
Mugenda, O. M., \& Mugenda, G. A. (1999). Research Methods: Qualitative and qualitative approaches. Nairobi: ACT Press

Mugo, D. G. (2007). Integrating emerging ICT technologies in science instruction. The successes and challenges facing NEPAD e-School project, a case study of Mumbi Girls' secondary school, Murang'a, Kenya. Unpublished Master of Education thesis, Nairobi: Kenyatta University

Neuman, L. W. (2008). Social Research Methods and quantitative approaches, (4 $4^{\text {th }}$ edition). Boston: Pearson Education Company

Nganga, S. I. et al. (2009). Fundamentals of management research Method. Nairobi: Macmillan Kenya Publishers

Nonyongo, E., Mabusela, K., \& Monene, V. (2004). Effectiveness of SMS Communication between University And Students Institute for Continuing Education, University of South Africa. Retrieved from http://www. mlearn.org.za/CD/papers/Nonyongo\&\%20 Mabusela. pdf on $15^{\text {th }}$ July 2016

Orina, W. M. (2000). Availability, acquisition and utilization of Instructional Resources for Teaching Geography in selected Kisii District Schools. Unpublished Master of Education thesis, Nairobi: Kenyatta University

Rafael, B., Michael, R., \& Jennifer, G. S. (2005). The Smart Phone: A Ubiquitous Input Device. https:/hci. rwthaachen.de/materials/publications/ballagas 2005d.pdf

Parasuraman, A. (2008). Technology Readiness and Its Implications for Technology-Based Customer service, University of Miami, Purdue Symposium: $10^{\text {th }}$ October 2008. Retrieved from http://www.purdue.edu/discoverypark/tcss/pdfs/parasuraman.pdf on 13 November 2014

Renner, T. (2013). Mobile OS - Features, Concepts and Challenges for Enterprise Environments Thomas Renner SNET Project Technische Universitat. Retrieved from https://www.snet.tu-berlin.de/fileadmin/fg220/ courses/SS11/snet-project/mobile-os-features_renner. pdf on $15^{\text {th }}$ April 2016

Sahin, Y. G., Balta, S., \& Tuncay, E. (2010). The use of internet resources by university students during their course projects elicitation: a case study The Turkish Online Journal of Educational Technology April 2010, volume 9 Issue 2. The Turkish Online Journal of Educational Technology 234

Samsung Electronics America, Inc. (2012). Samsung MobilePrint App. Retrieved from http://www.samsung. com/us/pdf/mobileprint-app-solutions.pdf $2^{\text {nd }}$ June 2016

Sharples, M. (2007). A short history of mobile learning and issues to consider. Learning Science Research Institute, University of Nottingham. Retrieved on $11^{\text {th }}$ August 2015 from http://www.slideshare net/sharp lem/history-of-mobile-learning-mlearn-2007-doctoral-consortium-Oct-2007

Solomon, A. D. (2013). A critical understanding of Learning Management System, Retrieved on $8^{\text {th }}$ August 2015 from http://www.academia.edu

Suki, N. M., \& Suki, N. M. (2009). Are lecturers ready to for usage of Mobile Technology for Teaching? Interna- 
tional Journal of Social, Behavioral, Educational, Economic, Business and Industrial Engineering, Volume 3, No 6, page 1-10

Tapio, V. (2005). The future of eLearning. A Short History of eLearning and a Look into the Future of Computer Mediated Learning. Swedish School of Social Science University of Helsinki.

UNESCO, (2011). From text books to telephone, Retrieved from www.UNESCO.org on 18-5-12

(2011). Mobile Learning Week Report on New learning cultures, opportunities and challenges of the digital world. www.UNESCO.org, Retrieved 7-9-14
Venkatesh, V. \& Davis (2000) A theoretical extension of the technology acceptance model: four longitudinal field studies," Management science, vol. 46, pp. 186-204

West, D. M., \& Lu, J. (2009). Comparing technology innovation in the private and public sectors. Government studies at Brookings. Atlanta.

Zab, S. (2015). The growth of Smart Phones in Kenya. Retrieved from https:/www.jumia.co.ke/blog/whitepaperthe-growth-of-the-Smart Phone-market-in-kenya/on $15^{\text {th }}$ July 2016

Zina, O. (2007). The Essential guide to doing research. New Delhi: Vistaar Publications. 